\title{
HISTOLOGICAL PICTURE OF THE WEAR PARTICLES AND THE BIOLOGICAL RESPONSE IN PERIPROSTHETIC TISSUE
}

\author{
HISTOLOŠKA SLIKA OBRABNIH DELCEV IN BIOLOŠKI \\ ODGOVOR V PERIPROTETIČNEM TKIVU
}

\author{
Andrej Cörr1,2 \\ ${ }^{1}$ Valdoltra Orthopaedic Hospital, Jadranska 33, 6280 Ankaran, Slovenia \\ ${ }^{2}$ Faculty of Health Sciences, Polje 42, 6130 Izola, Slovenia \\ Prejem rokopisa - received: 2018-07-18; sprejem za objavo - accepted for publication: 2018-09-27
}

doi:10.17222/mit.2018.160

\begin{abstract}
Implant loosening secondary to osteolysis is the most common mode of failure for joint prostheses. The generation of wear debris from any part of a prosthesis is unavoidable. This article will emphasize, with a careful morphological analysis, the interactions of different wear particles and biological host responses in periprosthetic tissue retrieved during revision arthroplasties due to aseptic loosening. Tissue samples for histological analysis were obtained during revision surgeries in the Valdoltra Orthopaedic Hospital. Wear particles in the periprosthetic tissue were analysed according to their size, shape, colour and properties, observed by conventional light microscopy and under polarized light. Wear particles from polymers such as polyethylene and polymethylmetacrylate, metals and ceramics induce an extensive biological cascade of adverse cellular responses, in which macrophages are the main cellular type involved in the hostile inflammatory process. Histological analysis of the tissue obtained during implant revision surgery is considered important for wear-particle identification, and for the classification of biological reactions to wear particles. In view of the continuous development of new biomaterials, a standardised histological examination of periprosthetic tissue provides a useful tool for determining the cause of implant failure and for identifying wear particles by light-microscopy examination. It also provides a basis for the advanced analysis of implant wear, molecular gene expression and cytokine production.

Keywords: wear particles, histological analysis, periprosthetic tissue
\end{abstract}

Aseptično omajanje kot posledica osteolize (raztapljanja kostnega tkiva) je najpogostejša oblika omajanja sklepnih protez. Vzrok so obrabni delci (delci, nastali zaradi obrabe), ki neizogibno nastanejo v katerem koli delu proteze. V članku je z natančno morfološko analizo predstavljena povezava med obrabnimi delci in biološkim odzivom obproteznega tkiva, odvzetega med revizijsko operacijo menjave sklepne proteze zaradi aseptičnega omajanja. V Ortopedski bolnišnici Valdoltra se vzorci obproteznega tkiva za histološko analizo odvzamejo pri skoraj vseh revizijskih operacijah. S klasičnim svetlobnim mikroskopom in $\mathrm{Z}$ uporabo polarizirane svetlobe smo analizirali obrabne delce v obproteznem tkivu glede na njihovo velikost, obliko, barvo in druge lastnosti. Obrabni delci iz polimerov, kot so polietilen in polimetilmetakrilat ter kovinski in keramični delci, povzročajo obsežno biološko kaskado neželenih celičnih odzivov, vodilno vlogo pri tem vnetnem procesu pa igrajo makrofagi. Histološka analiza tkiva, pridobljenega med revizijsko operacijo zamenjave sklepne proteze, je pomembna za prepoznavanje obrabnih delcev in za ugotavljanje vrste vnetne reakcije obproteznega tkiva na obrabne delce. Zaradi nenehnega razvoja novih biomaterialov je standardiziran histološki pregled obproteznega tkiva s pomočjo svetlobnega mikroskopa koristno orodje za določanje vzroka omajanja proteze ter za določitev obrabnih delcev. Obenem pa predstavlja osnovo za nadaljnjo analizo in izolacijo obrabnih delcev, molekularno analizo izražanja genov in tvorbe citokinov v obproteznem tkivu.

Ključne besede: obrabni delci, histološka analiza, obprotezno tkivo

\section{INTRODUCTION}

The increasing numbers of arthroplasties (several million per year worldwide) and expanding indications for this procedure have consequently led to an increasing number of revisions (about $10 \%$ of patients). ${ }^{1}$ In 2014, 4035 hip and 2481 knee prostheses were inserted in Slovenia. Based on demographic trends, an increase in needs for hip and knee prostheses of at least $40 \%$ annually is expected in the next 40 years. ${ }^{2}$ Some joint prostheses fail during the period of service and the main reason for the late failure of joint prostheses is aseptic loosening, accounting for around $75 \%$ of failures.

Since the pioneering work of Willert et al. ${ }^{3}$ there has been a tendency to associate aseptic loosening with local

*Corresponding author e-mail: andrej.coer@ob-valdoltra.si tissue response to wear debris generated from the surfaces of the prostheses. The generated debris can have one of two different forms: soluble ions or insoluble particles, which aggregate with serum protein forming protein-particle complexes of various sizes. ${ }^{4}$ Wear particles can be generated from any part of a prosthesis. An adverse response to implant wear particles with an abundance of macrophages and giant cells shows a direct relationship with the degree of bone resorption and is widely recognised as a significant cause of aseptic implant failure. Histological analyses of the synovial-like interface membrane (SLIM), which is a fibrous pseudocapsule around a prosthesis, can provide important information about the mechanisms involved in prosthesis loosening. This article will emphasize, with a careful morphological analysis, the interactions of different wear particles and biological host responses in periprosthetic 
tissue retrieved during revision arthroplasties due to aseptic loosening.

\section{MATERIALS AND METHODS}

A histological analysis of SLIM is systematically presented. All the cases were selected retrospectively from the pathology archives of the Valdoltra Orthopaedic Hospital and examined by a pathologist specialised in orthopaedic pathology. Particle categories were described according to their size, shape, colour and properties observed under conventional and polarized-light microscopy on hematoxylin and eosin, as well as on histochemically stained histological slides. The criteria used for particle identification are based on those previously described in the scientific literature. ${ }^{5}$ The inflammatory host response is fully described with illustrated examples.

\section{RESULTS}

The conventional histological analysis of the periprosthetic tissue obtained during revision surgery revealed a wide spectrum of foreign-body reactions, from the spare accumulation of macrophages to severe dense macrophage and giant cells infiltration. A foreign-body reaction is a biological response to wear particles from polyethylene (PE), metallic debris (conventional and corrosion), ceramic and polymethyl methacrylate orthopaedic cement (PMMA). The most frequent combinations of wear materials occur on the basis of the implant-bearing surface: metal on polyethylene $(\mathrm{MoP})$, ceramic on polyethylene $(\mathrm{CoP})$, metal on metal (MoM), and ceramic on ceramic (CoC).

A detailed cytological examination of SLIM demonstrated that 70-90\% of the debris load consists of polyethylene (PE). PE particles can easily be identified by their characteristic appearance with light microscopy and under polarised light. PE microparticles are located in the cytoplasm of macrophages and they measure $\leq 5$ $\mu \mathrm{m}$. Macrophage cytoplasm filled with PE microparticles can be visualised by special oil-red-O staining (Figure 1b). PE macroparticles measure between $>5 \mu \mathrm{m}$ and $>100 \mu \mathrm{m}$ and are phagocytised by multinucleated giant cells. Supramacroparticles (up to several $\mathrm{mm}$ ) are

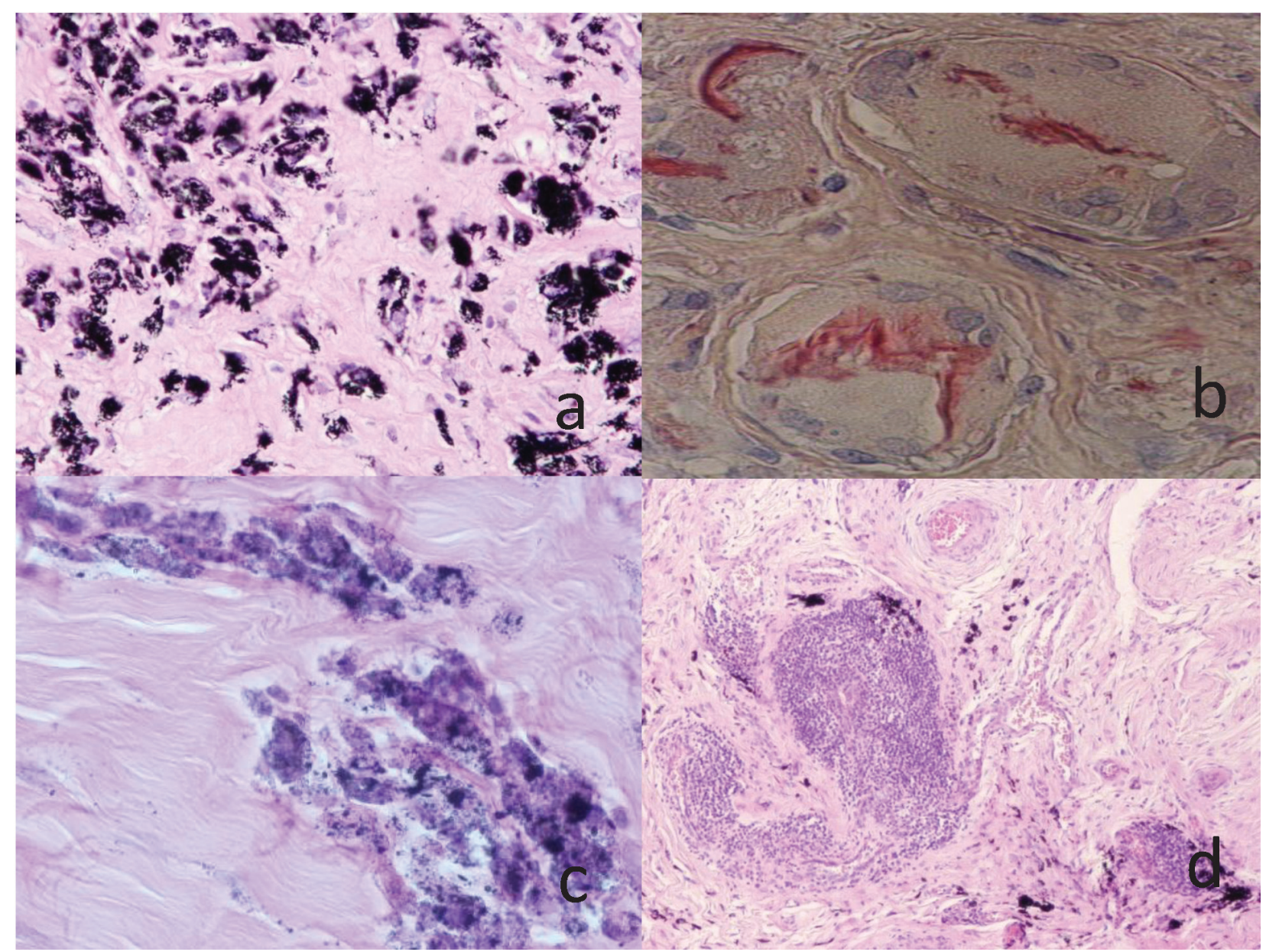

Figure 1: a) Metal microparticles: intensely black, mainly aggregated intracytoplasmic particles, b) polyethylene macroparticles: phagocytosed by giant cells and stained by Oil-o-red staining, c) ceramic particles: yellowish grey in macrophage cytoplasm and also extracellular, d) perivascular lymphoid aggregates in periprosthetic tissue from a metal-on-metal hip prosthesis. 
surrounded by giant cells or are sometimes located extracellulary.

Metals and their alloys, increasingly used for arthroplasty, usually contain titanium, tantalum, aluminium, vanadium, cobalt, molybdenum, chromium, niobium and nickel, in various combinations. Metallic wear particles are very small, with a diameter ranging from $0.05 \mu \mathrm{m}$ to $<5 \mu \mathrm{m}$ if they are not presented in aggregated form. The shape is predominately rod/needle-like, but can vary from round to polygonal. Their colour varies from grey to jet-black and they exhibit no, or only minimal, birefringence (Figure 1a).

Wear-induced ceramic particles usually occur in the size range of $20-100 \mathrm{~nm}$ up to several $\mu \mathrm{m}$. In rare cases of ceramic component fracture, macroparticles up to a few $\mathrm{mm}$ can be detected in SLIM. Ceramic particles are variable in colour, mostly yellowish-brownish or greybrown to blackish (Figure 1c). The birefringence of the microparticles varies from absent to weak.

Polymethylmethacrylate (PMMA) particles are chemically dissolved during the conventional histological tissue preparation procedure. They can be identified by light microscopy as empty vacuole-like cavities of variable size, lined or engulfed by multinucleated giant cells. Zirconium dioxide and/or barium sulphate added as an X-ray marker can be detected within PMMA cavities as intensely black deposits.

Any foreign material in the body initiates an innate foreign-body response. The bio-reactivity of wear particles depends on the particle characteristics (size, concentration and composition) and host characteristics. ${ }^{4}$ Prosthetic wear particles induce an extensive biological cascade of adverse cellular response, in which activated macrophages are the main cellular type involved. Consequently, granulomas (nodules consisting of inflammatory cells phagocytizing the foreign bodies) with necrosis, necrobiosis and fibrosis, can form within periprosthetic tissue. Scattered lymphocytes may also exist but are not a prominent finding.

In addition to the innate immune response, implantderived wear particles also induce an adaptive immune response. Histologically, this is demonstrated by the presence of lymphoid cells, particularly lymphocytes within SLIM. Pronounced, often heavy perivascular lymphoid aggregates, termed aseptic lymphocyte-dominated vasculitis associated lesions (ALVAL), can be seen in response to metal wear particles and ions and are thought to develop as a result of a delayed (type-IV) hypersensitivity reaction. ${ }^{6}$ In relation to MoM implants, $\mathrm{CoCr}$ particles produce high levels of metal ions, which can act as haptens, which combine with large carrier protein molecules to become immunogenic. The histological picture of a cell-mediated hypersensitivity reaction consists of pseudotumours (solid and/or cystic masses, which show features of both innate and adaptive immune reaction to metal particles, which communicate with the prosthetic joint) and heavy perivascular lymphoid aggre- gates, macrophage response and granuloma formation (Figure 1d).

\section{DISCUSSION}

The success of arthroplasty depends on choosing the right operation for the right patient and performing the operation meticulously with state-of-the-art materials. ${ }^{7}$ Younger, more active, patients now expect their joint replacements to last for their lifetime without physical limitations. Implant-related pathologies are now moving into the focus of scientific interest. ${ }^{8}$ Several studies have investigated the specific biomaterial-dependent variability in periprosthetic tissue, in an attempt to clarify how the type of prosthetic particles or ions (in the case of metal components) influences the structure of periprosthetic tissue. ${ }^{9}$ Little agreement exists on what type of wear debris is more bio-reactive, but there is a growing consensus that metallic debris is more proinflammatory in vivo than polymer debris. A histopathological algorithm has been proposed that offers a guide to particle identification in SLIM and better interpretation of implant-tissue interaction and we use this algorithm in routine daily practice. ${ }^{8}$

A histological analysis of periprosthetic tissue removed during revision arthroplasties is still not mandatory in many orthopaedic hospitals. In the Valdoltra Orthopaedic Hospital, tissue samples for histological analysis are obtained during more than $80 \%$ of revision arthroplasties. The first goal of our histopathological evaluation is to differentiate between septic and aseptic types of periprosthetic tissue, which is important for a treatment decision. However, we believe that the histology of periprosthetic tissue can contribute significantly to our knowledge of the mechanisms of aseptic loosening and periprosthetic osteolysis.

A histological analysis of retrieved periprosthetic tissue has several limitations, such as heterogeneity in the patient, surgeon and implant characteristics, inability to harvest tissue at the different stages of tissue changes before final aseptic loosening and the lack of standardised sampling and processing methodologies. ${ }^{9}$ However, a histological analysis of wear particles and host-tissue biological response in periprosthetic tissue is advisable, since it can provide some important information for materials scientists and orthopaedic surgeons as well as valuable data for the risk assessment of implant performance for regional and national implant registers and government agencies. ${ }^{7}$ It has to be integrated with clinical, alergological, microbiological, imaging and biomechanical findings for optimal results.

\section{CONCLUSIONS}

The histological findings of periprosthetic tissue reflect the pathobiology of the innate or adaptive host response to wear particles. A standardised histological 


\section{A. CÖR: HISTOLOGICAL PICTURE OF THE WEAR PARTICLES AND THE BIOLOGICAL RESPONSE ...}

analysis of morphological characteristics in periprosthetic tissue and the basic characterisation of wear particles is a reliable and reproducible method for determining the cause of arthroplasty failure and provides a basis for the advanced analysis of implant wear particles and molecular methods for gene expression and cytokine production examinations.

\section{REFERENCES}

${ }^{1}$ G. Krohmer, N. Koleganova, P. T. Hadjicostas, B. Fink, I. Berger, Degenerative changes of the interface membrane as a possible reason for prosthesis loosening, Histol. Histopathol. 23 (2008) 8, 925-933, doi:10.14670/HH-23.925

${ }^{2}$ B. Mavčič, Potrebe po endoprotezah kolka in kolena v Sloveniji do leta 2050, Med. Razg., 55 (2016) 1, 5-12

${ }^{3}$ H. G. Willert, M. Semlitsch, Reactions of the articular capsule to wear products of artificial joint prostheses, J. Biomed. Mater. Res., 11 (1977) 2, 157-164
${ }^{4}$ D. Bitar, J. Parvizi, Biological response to prosthetic debris, WJO 6 (2015) 2, 172-189, doi:10.5312/wjo.v6.i2.172

${ }^{5}$ H. G. Willert, M. Semlitsch, Tissue reactions to plastic and metalic wear products of joint endoprostheses, Clin. Orthop. Relat. Res., 333 (1996), 4-14

${ }^{6}$ N. A. Athanasou, The pathobiology and pathology of aseptic implant failure, Bone Joint Res., 5 (2016) 5, 162-168, doi:10.1302/20463758.55.BJR-2016-0086

${ }^{7}$ J. Pajarinen, T. H. Lin, T. Sato, Z. Yao, S. B. Goodman, Interaction of materials and biology in total joint replacement: - successes, challanges and future directions, J. Mater. Chem. B., 41 (2014) 2, 7094-7108, doi:10.1039/C4TB01005A

${ }^{8}$ V. Krenn, J. A. Kretzer, P. Thomas, et al., Update on endoprosthesis pathology: Particle algorithm for particle identification in the SLIM, Seminars Artroplasty, 24 (2013), 265-275

${ }^{9}$ J. Gallo, J. Vaculova, S. Goodman, Y. Konttinen, J. Thyssen, Contribution of human tissue analysis to understand the mechanisms of loosening and osteolysis in total hip replacement, Acta Biomater., 10 (2014) 6, 2354-2366, doi:10.1016/j.actbio.2014.02.003 